\title{
Palmyra Fiber as Additional Materials on Solid Concrete Brick of Aggregate
}

\author{
Asrial 1 \\ Antariksa ${ }^{2}$ \\ Amin Setyo Leksono 3 \\ Serafinah Indriyani ${ }^{4}$
}

${ }^{1}$ Graduate School of Environmental Science, Brawijaya University Malang and Department of Technical Building Education, Nusa Cendana University, East Nusa Tenggara, Indonesia

2Department of Architecture, Faculty of Engineering, Brawijaya University, Malang, East Java, Indonesia,

${ }^{3}$ Department of Biology, Faculty of Mathematics and Natural Sciences, Brawijaya University, Malang, East Java, Indonesia

Email; asrialchatib@gmail.com

Doi:10.5901/mjss.2017.v8n1p410

\section{Abstract}

The use of waste as an additional material on the building work was increasingly actively developed, such as straw, styrofoam, bagasse, cow manure. The key drivers of the use of waste is the potential for waste is increasing, due to the depletion of nonrenewable resources. Papyrus rod diameter $60 \mathrm{~cm}$, length 30 meters, has a volume of $5,652 \mathrm{~m}^{3}$ as well as the edges of the Rods that can be used for construction with a thickness of $3 \mathrm{~cm}$ has a volume $0,942 \mathrm{~m}^{3}$, Pith and fiber volume content of the stem $4,71 \mathrm{~m}^{3} / \mathrm{rod}$, then in one rod, there are 2 to 3 bunches each fruit bunches yield as much as 20 to 30 items for one harvest, by weight of fruit fiber $101.2 \mathrm{gram} /$ fruit, Fiber characteristics are round and smooth is expected to reduce cracks in solid concrete brick and also can reduce the use of sand. This study aims to determine the compressive strength of the composition of the additional material of Rods fiber content and Fiber of palmyra fruit with a percentage $3 \%, 6 \%$ and $9 \%$, mixing ratio; 1 cement and 5 sand in the manufacture of solid concrete brick. Rods fiber content used the average $\varnothing 1,031 \mathrm{~mm}$ with a tensile strength of single fiber $39,305 \mathrm{~N} / \mathrm{cm}$ and fruit fiber to an average value $\varnothing 0,40 \mathrm{~mm}$ with a tensile strength of single fiber $33,691 \mathrm{~N}$ $/ \mathrm{cm}$. Making test specimen with a length of $20 \mathrm{~cm}$, width $10 \mathrm{~cm}$ and thick $8 \mathrm{~cm}$. The test results of compressive strength after 14 days with the lowest value at $3 \%$ of additional material combination of fiber content of $6 \%$ fiber stem and fruit by $70,384 \mathrm{Kg} / \mathrm{cm}^{2}$ with a water content of $15,254 \%$ In weight position $2,935 \mathrm{Kg}$ as well as the highest value on the combination of additional material $0 \%$ rods fiber content and $3 \%$ fruit fiber by $98,821 \mathrm{Kg} / \mathrm{cm}^{2}$ with a water content of $15,031 \%$ In weight position $3,058 \mathrm{Kg}$. While $N$ (without additional material) with a compressive strength below the average id $63,704 \mathrm{Kg} / \mathrm{cm}^{2}$ with water content of 10,167 in weight position 3,072Kg. Research result of solid concrete brick with additional material of rods fiber content and palmyra fruit fiber was included on the type B70, the average value of the compressive strength of $78.57 \mathrm{Kg} \mathrm{/} \mathrm{cm}{ }^{2}(\mathrm{SNI}-03-$ 1348-1989) with a water content of $<25 \%$.

Keywords: Rods Fibers Contents, Palmyra Fruit Fiber, the Quality of Solid Concrete Brick

\section{Introduction}

The increase of construction development in the field todays can be seen from the use of materials in improving the quality of the building which is characterized by higher usage of new basic materials. The use of new base material due to depletion of the utilization of nonrenewable resource and efforts to improve the quality of buildings such as utilizing environmentally friendly waste in improving the quality of material. Basically the use of additional material in building construction have more strength and environmentally friendly. Utilization of waste in the manufacture of building materials can reduce the material utilization of non-renewable resources.

Palmyra rod has a diameter of $60 \mathrm{~cm}$ with a length of 30 meters, has a rods volume of $5.652 \mathrm{~m}^{3}$, parts of the skin with an average thickness of $1 \mathrm{~cm}$, part of which can be used for construction materials with a thickness of $3 \mathrm{~cm}$ with a total volume of $0,942 \mathrm{~m}^{3}$. Only rods contents side are having a volume of $4,71 \mathrm{~m}^{3} / \mathrm{rod}$. The outer part of the Palmyra palm on which is heavy, hard and blackish in color is used as a building material or for making utensils and handicrafts (Lestari et al., 2013). At the opening of the land in the construction of road and in the city of Kupang on a collection of Palmyra palm, occur logging and burning of Palmyra palm in large numbers. The use of construction materials is only part of rod which is hard and black colors (Lempang et al., 2012). Palmyra fruit that has to ripen and fall has not been used by the public, although the potential of fruit, in one rod there are 2 to 3 bunches each clusters that produce 20 to 30 pieces. Boimau research results, et al., (2012) tensile test values obtained for the highest tensile strength of Palmyra fiber composite by 14,23 MPa on Vf 30\%, Lowest tensile strength of 8,62 MPa. 
The processing of additional materials of the Palmyra Rods Fibers pass the analysis testing, the testing result $\mathrm{NaOH}$ done using sodium hydroxide concentration of $4 \%$ for 24 hours is the procedure of choice for fiber firmness Machaka et al., (2014), some of the advantages of embedding these fibers can be an alternative option of natural fibers to reinforce thermoplastic (Bachtiar et al., 2011). Use of construction materials based on renewable resources such as vegetable fiber that is necessary to do research as amplifier cement-based materials, including fiber characteristics, nature and description of the fiber, the average tensile strength test results of palmyra of rods fiber of Physics Laboratory Brawijaya university amounted $39,305 \mathrm{~N} / \mathrm{cm}$ and fruits fiber $33,691 \mathrm{~N} / \mathrm{cm}$, with the percentage of the additional fiber material for the drafting of the test specimen of solid concrete brick.

Results of waste management, such as Styrofoam waste, rice husks, paper, plastic and wood can be used as an alternative building materials, and has been tested benefits, both physical and mechanical, (Kurniaty et al., 2011). Suwarto et al., (2011) utilize fiber reeds to manufacture lightweight brick with holes, then the study of Hartono (2011) concluded that waste wood sawdust mixed with cement can be processed into aggregate and can be used as building materials such as cement bricks. This is supported by Nugroho and Annur (2014) which uses cow manure waste materials that can be recycled into a building material.

The use of recycled materials and waste is now highly influential in the construction industry and can save energy, costs and does not cause environmental problems (Bolden, 2013). Local building materials which are produced can reduce the construction cost of about 60 percent (Iwuagwu, 2015). Hollow concrete blocks more lighter and cheaper production costs than standard PU and the market and has a compressive strength greater than market standards and meet environmental quality standards (Mizwar, 2012).

The problems that arise from the remainder of Palmyra rod production are the rods contents fiber and pith is still there which waste becomes, Fiber from palmyra fruit not fully utilized, extracting clay on the productive land for brick making is still ongoing, how the quality of solid concrete brick with additional materials fibers of Palmyra palm, many types of fiber on the market, for the purpose of environmental protection more widely used natural fibers rather than synthetic fibers, (Machaka, 2014)

The purpose of this paper is generally utilize waste of Palmyra palm as an alternative to reduce the use of nonrenewable resources, specifically to determine the compressive strength of concrete solid brick using additional materials rods fiber contents of Palmyra palm, Palmyra fruit fiber and quality of solid concrete brick which is using rods fiber contents and dan Palmyra fruit fiber through the compressive strength test.

\section{Research Methods}

\subsection{Research Location}

The time of taking materials of rods fiber contents in Oebelo village, Central Kupang district, while fruit fiber in Oesapa coast of Kupang city, testing the tensile strength of single fiber at the Laboratory of Physics of Natural Sciences Faculty of Brawijaya University, The test specimens manufacture and compressive strength testing was in Building Materials testing center of Public Works Service, East Nusa Tenggara Province.

\subsection{Tools and materials}

Observations and measurements of fiber diameters using a cooling tech the optimum resolution microscope 50-500x digital zoom and caliper digital, Testing the tensile strength of single fiber brand IMADA capacity of $50 \mathrm{kN}$, small digital scales for fibers with 2 decimal precision and scale for digital test object exellent JCS-B capacity $30 \mathrm{Kg} / 1 \mathrm{~g}$ with 3 decimal precision.

The testing water content is using the Memmert brand of heating machine with a capacity up to $2000 \mathrm{C}$, with a compressive strength testing machine MBT (material testing equipment) force gauge capacity of $1500 \mathrm{kN}$.

Materials used in the form of fibers from palmyra rods contents and fibers from palmyra fruit, rods fibers contents is the residue of the processing of palmyra rods, the processing of this rods fibers contents washed so that the dirt can be separated and dried by sunlight \pm 4 hours. Fibers from palmyra fruit elected directly, the fruit is ripe and fall under palmyra palm located in tourist sites the Nunsui coastal of Oesapa village, Kelapa Lima sub-district, Kupang city, processing by way separated from the seeds using scissors, then washed to remove dirt and dried in sunlight \pm 4 hours. Rods fibers contents and fruit fiber that has dried cut using scissors along $1.5-2 \mathrm{~cm}$ for use as additional materials for making the Solid Concrete Brick.

Examination of portland cement production of cement Kupang with a weight of $40 \mathrm{Kg} / \mathrm{sack}$, density of 3.15, gray no grain agglomerates so can be directly used, the sand examination ex. Takari of Kupang district with a density of 2.56, water absorption $1,12 \%$ and the levels of mud $1,41 \% \leq 5 \%$ sand examination refers to (SNI 03-4142-1996). 
The microscope is used to observe rods fiber content, rough surface, the diameter of 1-1.5 mm a round shape with a yellowish color There are black spots and density 0.3 and length can reach a of $50 \mathrm{~cm}$. The Observation of fruits fiber with more delicate surfaces $0.2-0,6 \mathrm{~mm}$ diameter, round shape with a yellowish color and density 0.1 as well as the length can reach $10 \mathrm{~cm}$. The water used comes from PDAM (Regional Water Company) of Kupang city which density was 1.

The measurement of Palmyra rods fiber by taking the average of the three strands of fiber determined by measuring the mean of each strand of each diameter at three points which are different. Measurement of Palmyra fruit fiber by taking the average of the four strands of fiber are determined by measuring the mean of each strand, each diameter at three points which are different. formula:

Ratio calculation of the volume of additional material by testing the density of each additional material by using

$$
\begin{aligned}
& \frac{x \mathrm{PC}}{\mathrm{bjPC}}+\frac{x \mathrm{PS}}{\mathrm{bjPS}}+\frac{x \mathrm{~W}}{\mathrm{bjW}}=1 \\
& \text { Notation: } \\
& x=\text { Comparison value between the aggregate } \\
& \mathrm{PC}=\text { Cement } \\
& \mathrm{PS}=\text { Sand } \\
& \mathrm{W}=\text { Water } \\
& \mathrm{Bj}=\text { Density }
\end{aligned}
$$

Comparison of the volume of $1 \mathrm{~m}^{3}$ converted to the size of the weight (Gram) to determine the percentage of additional material in the manufacture of test specimens, and the results of the calculations in Table 1.

\begin{tabular}{|c|c|c|c|c|}
\hline \multirow{2}{*}{\multicolumn{2}{|c|}{$\begin{array}{c}\text { Percentage } \\
\text { Additional materials } \\
\end{array}$}} & \multicolumn{2}{|c|}{ Weight } & \multirow{3}{*}{$\begin{array}{c}\text { Total } \\
\text { Object } \\
\text { Test }\end{array}$} \\
\hline & & Additional $\mathrm{m}$ & & \\
\hline Rods fiber contents & Fruit fiber & Rods fiber contents (gram) & Fruit fiber (gram) & \\
\hline \multirow{4}{*}{$0 \%$} & $0 \%$ & 0 & 0 & 3 \\
\hline & $3 \%$ & & 2,13 & 3 \\
\hline & $6 \%$ & & 4,26 & 3 \\
\hline & $9 \%$ & & 6,39 & 3 \\
\hline \multirow{4}{*}{$3 \%$} & $0 \%$ & 2,17 & 0 & 3 \\
\hline & $3 \%$ & & 2,13 & 3 \\
\hline & $6 \%$ & & 4,26 & 3 \\
\hline & $9 \%$ & & 6,39 & 3 \\
\hline \multirow{4}{*}{$6 \%$} & $0 \%$ & 4,35 & 0 & 3 \\
\hline & $3 \%$ & & 2,13 & 3 \\
\hline & $6 \%$ & & 4,26 & 3 \\
\hline & $9 \%$ & & 6,39 & 3 \\
\hline \multirow{4}{*}{$9 \%$} & $0 \%$ & 6,52 & 0 & 3 \\
\hline & $3 \%$ & & 2,13 & 3 \\
\hline & $6 \%$ & & 4,26 & 3 \\
\hline & $9 \%$ & & 6,39 & 3 \\
\hline \multicolumn{4}{|c|}{ Total } & 48 \\
\hline
\end{tabular}

Table 1. The percentage of additional material one test specimens. The composition of raw material for brick $\left(\mathrm{m}^{3}\right)$

\begin{tabular}{|l|c|c|c|c|c|}
\hline \multirow{2}{*}{ Materials } & \multirow{2}{*}{ Density } & \multirow{2}{*}{ Agregate $\left(\mathrm{m}^{3}\right)$} & \multicolumn{3}{|c|}{ Amount of filaments as additional material (Gr). } \\
\cline { 4 - 6 } & & & $3 \%$ & $6 \%$ & $9 \%$ \\
\hline Cement & 3.15 & 0.16 & - & - & - \\
\hline Sands & 2.56 & 0.80 & - & - & - \\
\hline Water & 1 & 0.04 & - & - & - \\
\hline Filaments & 0.1 & - & 2.13 & 4.26 & 6.39 \\
\hline Rods fiber contents & 0.245 & - & 2.17 & 4.35 & 6.52 \\
\hline
\end{tabular}

The test object is made with ingredients 1semen and 5 sand, a combination of percentage comparison additional materials rods fiber contents and fruit fiber contents $0 \%, 3 \%, 6 \%$ and $9 \%$, and 3 repetitions, thus totaling 48 specimen, the combination ratio of additional materials in Table 2.

Table 2. Ratio combined of additional materials of each specimen. 
Making the test object, through the mixing of materials of cement and sand until blended, coupled with water and mixed again until blended (1), then increasing the percentage of fiber in each specimen and mixed again until blended (2), mold size of solid concrete brick with a length of $20 \mathrm{~cm}$, width $10 \mathrm{~cm}$ and thick $8 \mathrm{~cm}$. Mixtures (1) and (2) is inserted into a mold and solidified by mashing with square wooden stake 15 times and flattened, after 7 to 10 minutes released from the mold by numbering and aerated for 14 days. Determine the water content in a way, the test specimen is immersed in a container filled with clean water for 24 hours, the specimen weighed $(A)$ is then inserted in the machine heater with temperature $110^{\circ} \mathrm{C}$ for 24 Hours, The next test specimen weighed (B), to determine the absorption of water using the formula:

$$
=\frac{A-B}{B} \times 100 \%
$$

Compressive strength testing in a way, in pairs practitioners at the top and bottom sides 3mm maximum, three days before the compressive strength test performed, testing the compressive strength of concrete solid brick after the age of 14 days (SNI-03-0348-1989), determine the extent of the specimen (A), the pointer on the monitor stops at the maximum force $(F)$, the compressive strength $(\sigma)$ with formula:

$$
\sigma=\frac{F}{A}
$$

\section{Results and Discussion}

\subsection{The measurement results rods fiber contents}

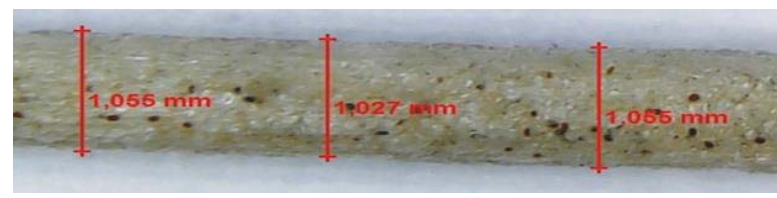

Figure 1. The measurement results palmyra rods fiber contents

The results of the measurement and testing of tensile strength single palmyra trunk fiber contents can be seen in Table 3 .

Table 3. Test tensile strength of single fiber of trunk contents

\begin{tabular}{|c|c|c|c|c|c|c|c|}
\hline & \multicolumn{3}{|c|}{ Measurement of } & Averages & Wide & Tensile & Fiber strenght \\
\cline { 2 - 8 } & $\mathrm{I}(\mathrm{mm})$ & $\mathrm{II}(\mathrm{mm})$ & $\mathrm{III}(\mathrm{mm})$ & $(\mathrm{mm})$ & $\left(\mathrm{mm}^{2}\right)$ & $\mathrm{N}$ & $\mathrm{N} / \mathrm{cm}^{2}$ \\
\hline FIBER A & 1,055 & 1,009 & 1,036 & 1,033 & 0,838 & 32,08 & 38,272 \\
\hline FIBER B & 1,027 & 1 & 1,064 & 1,030 & 0,833 & 20,45 & 24,540 \\
\hline FIBER C & 1,055 & 1,009 & 1,027 & 1,030 & 0,833 & 45,92 & 55,103 \\
\hline
\end{tabular}

Testing the tensile strength of single fiber contents palmyra rod using a tensile machine types IMADA 50kN capacity, with formula: $\sigma=\frac{F}{A}$,

$\sigma=$ Tensile Strength

$\mathrm{F}=$ Tensile Force

$A=$ Surface Area of the Fibers (SNI 03-0348-1989)

Fiber content of rods with an average diameter of $1,031 \mathrm{~mm}$ has a tensile strength of single $39,305 \mathrm{~N} / \mathrm{cm}^{2}$, Testing results of the single tensile strength of Palmyra trunk fiber contents in Figure 2. 

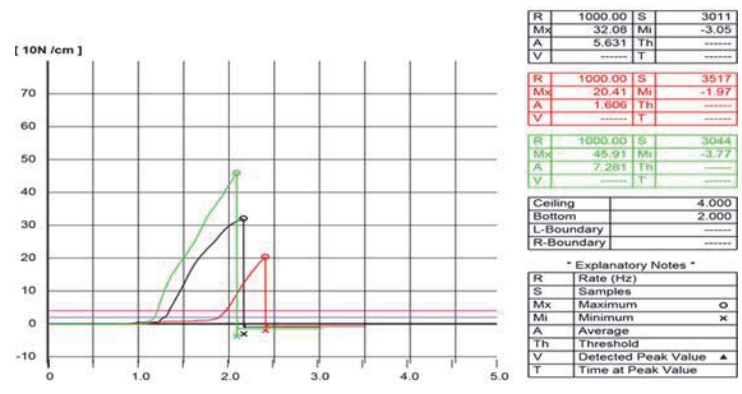

Figure 2. Results of testing the tensile strength single Palmyra rods fiber contents

3.2 The results of the measurement of palmyra fruit fiber

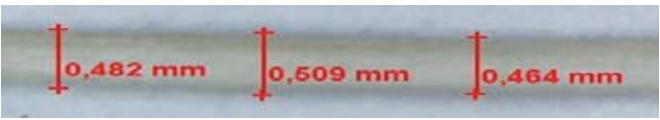

Figure 3. Measurements Results of Palmyra fruit fibers

Tools used to test the tensile strength of a single (single filament) with a tensile testing machine (Tensile strength of the Imada brand type yp50N), the strength of each fiber $\sigma=\frac{F}{A}$. The results of measuring the diameter of the fruit fiber average diameter of $0.40 \mathrm{~mm}$, with a tensile strength of the average single $45,144 \mathrm{~N} / \mathrm{cm}^{2}$, fiber test results in table 3 .

Table 3. Tensile strength test results of a single Palmyra fruit fiber.

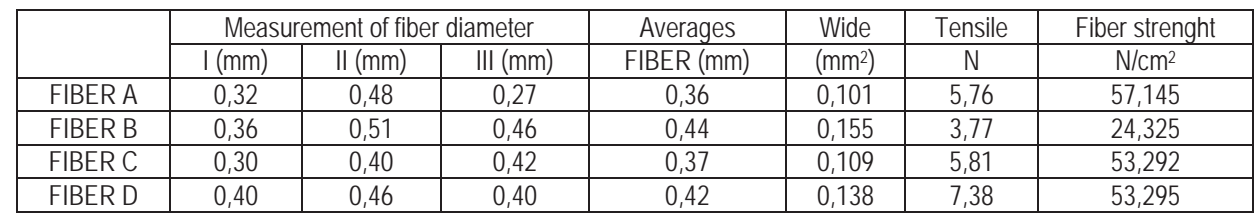

Testing Results Measurement of tensile strength of single fibers of Palmyra fruit with the average of the measurement results $\varnothing 0,40 \mathrm{~mm}$ has an average value of tensile strength $45,144 \mathrm{~N} / \mathrm{cm}^{2}$. The test results in Figure 4.
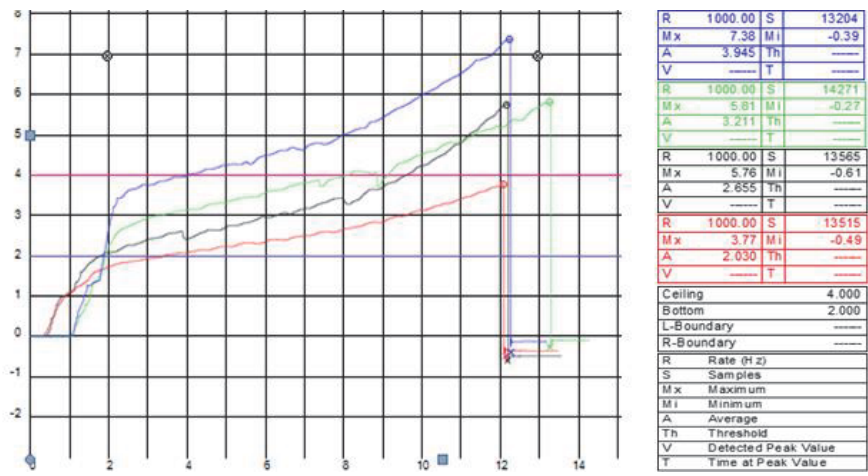

Figure 4. Testing Results of tensile strength of single fibers of Palmyra fruit [ $1 \mathrm{sec} / \mathrm{cm}$ ] * Print Date:2016-Jun-8(Wednesday) 10:40:51 AM 
Measurement of the test specimen has been done before it is put on the heating and after heated to determine water absorption in each specimen. The measurement results of the test specimen has been shrinking on average $0,34 \%$.

\subsection{The results of the analysis of water content}

The results of water content measurement by calculating the difference in weight weighing in wet conditions before $(A)$ and after through heating machine $110^{\circ} \mathrm{C}$ during 24 hours (B) using the formula:

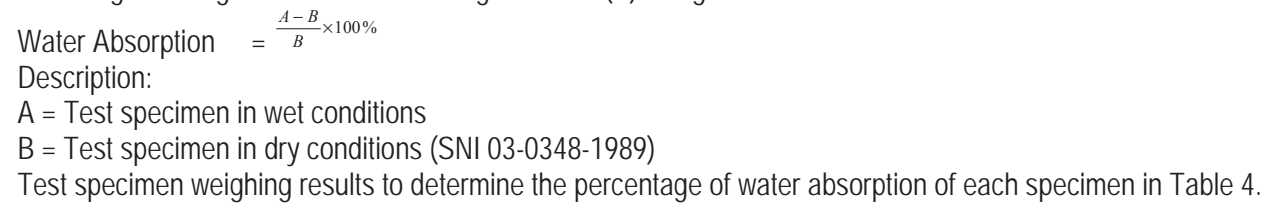

Table 4. Calculation results of water content percentage

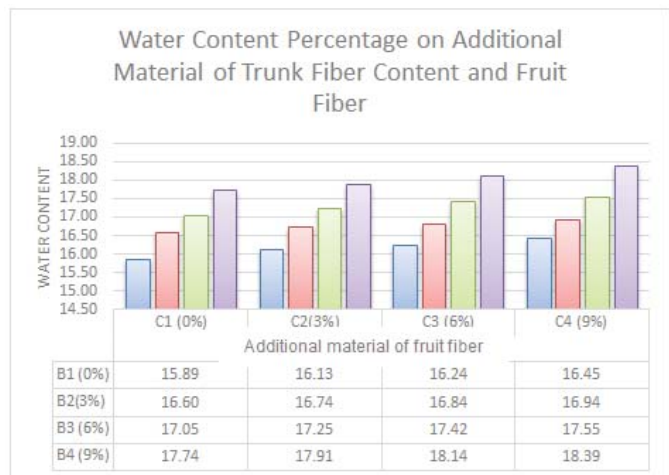

Notation: $B=$ specimen with additional material of rods fiber contents; $C=$ specimen with additional material of fruit fiber

The results of the analysis of water content known to the lowest value in comparison of rods fiber contents and fruit fiber B1 and C1 amounted 15,89\% (Specimen does not use additional materials), which uses additional materials with the percentage of water content slightly in B2, C1 amounted 16,60\%, while the highest value in comparison of rods fiber contents and fruit fiber B4 and C4 amounted 18,39\%, water absorption average 17,08\% < 25\% (SNI-03-1348-1989), The results of this study are supported by Susandra et al., (2014), The more the percentage of sawdust, then the higher the water content.

\subsection{The effect of the addition of rods fiber contents to the compressive strength of solid concrete brick}

Testing the compressive strength after the specimen aged 14 days, the compressive strength of concrete solid brick calculated using the formula:

$$
\sigma_{\mathrm{b}}=\frac{\mathrm{P}}{\mathrm{A}}
$$

Description:

$\mathrm{P}=$ Maximum load $(\mathrm{kg})$

$A=$ cross-sectional area of the field press $\left(\mathrm{cm}^{2}\right)$

$\sigma \_b=$ solid brick compressive strength $\left(\mathrm{kg} / \mathrm{cm}^{2}\right)$, (SNI 03-0348-1989)

The results of the analysis of the specimen with additional materials palmyra rod fiber contents of compressive strength is shown in Table 5 : 
Table 5. The average compressive strength of the Palmyra rod fiber content

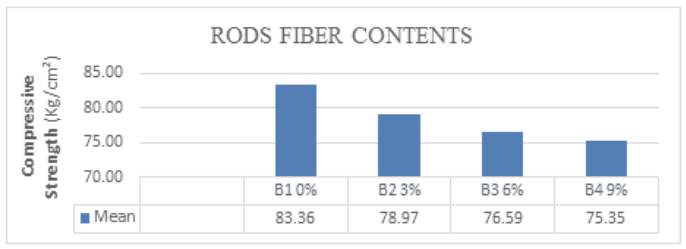

Based on Table 5, the lowest compressive strength found in the percentage of fiber trunk on level B4 (9\%) with an average of $75.35 \mathrm{Kg} / \mathrm{cm}^{2}$, while the highest level of compressive strength on level of B1 (0\%) with an average of 83.36 $\mathrm{Kg} / \mathrm{cm}^{2}$. Rod fiber with a level of $9 \%$ (B4) with $6 \%$ (B3) has the same effect on compressive strength in improving the quality of solid concrete brick; rods fiber content with percentage level 3\% (B2) and 0\% (B1) has the same effect on compressive strength in improving the quality of solid concrete brick, while rods fiber with percentage level $9 \%$ (B4) and $0 \%$ (B1) significantly different or have a different effect on the compressive strength in improving the quality of solid concrete brick.

Additional material rods fiber $0 \%$ (B1) and 3\% (B2) has compressive greater strength than dengan additional material rods fiber $6 \%(\mathrm{~B} 3)$ and $9 \%(\mathrm{~B} 4)$.

Rods fiber with a diameter up to $1.4 \mathrm{~mm}$ has a wider dimension, of the research results the more additional materials of Palmyra rod fiber content then the less the compressive strength, from the analysis of the compressive strength decrease to $7.69 \%$. The compressive strength to be decreased, the percentage of additional materials $(10,15$ and 20\%), Mokhtari et al., (2015), the compressive strength value of average is still above $70 \mathrm{Kg} / \mathrm{cm}^{2}$ appropriate quality B70 (SNI-03-1348-1989).

\subsection{The effect of the addition of fruit fiber to the compressive strength of solid concrete brick}

Testing result of the compressive strength after the specimen aged 14 days, Mean of fruit fiber to the compressive strength can be shown in the table 6 :

Table 6. The Mean of Compressive Strength of fruit fiber

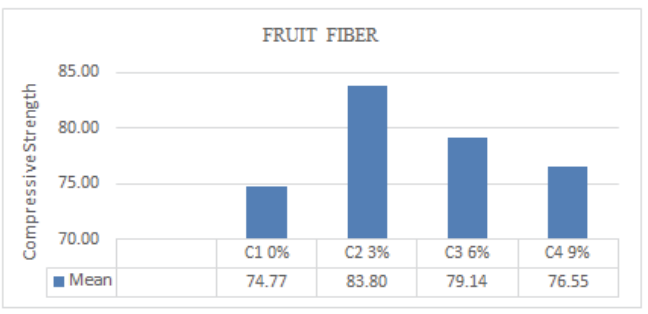

Based on Table 6, the percentage of fruit fibers are at least at the level $\mathrm{C} 1(0 \%)$ with an average compressive strength of $74.77 \mathrm{Kg} / \mathrm{cm}^{2}$, while the percentage of fruit fibers at level $\mathrm{C} 2(3 \%)$ had the highest compressive strength with an average of $83.80 \mathrm{Kg} / \mathrm{cm}^{2}$. Fruit fiber with a level of $0 \%$ (C1) with $9 \%(\mathrm{C} 4)$ has the same effect on the compressive strength of concrete in improving the quality of solid concrete brick; fruit fiber with a level percentage of $3 \%$ (C2) with a $6 \%$ (C3) has the same effect on compressive strength in improving the quality of solid concrete brick, while fruit fiber with a level percentage of $3 \%$ (C2) to $0 \%$ (C1) was significantly different or have a different influence of compressive strength in improving the quality of solid concrete brick, from the analysis of the increase in compressive strength of up to $6.76 \%$. The use of natural fibers for additional materials to strengthen the plaster and fiber-reinforced concrete, Abani. et al. (2015), and Nesibe et al., (2014)., Local building materials produced can reduce the construction cost of about 60 percent, Iwuagwu et al.,(2015) 


\subsection{The effect of the addition of rods fiber contents and fruit fiber to the compressive strength of solid concrete brick}

The effect of the addition of rods fiber contents and fruit fiber to the compressive strength of solid concrete brick. Testing result of the compressive strength after the specimen aged 14 days, Mean of fruit fiber to the compressive strength can be shown in the figure 3 :

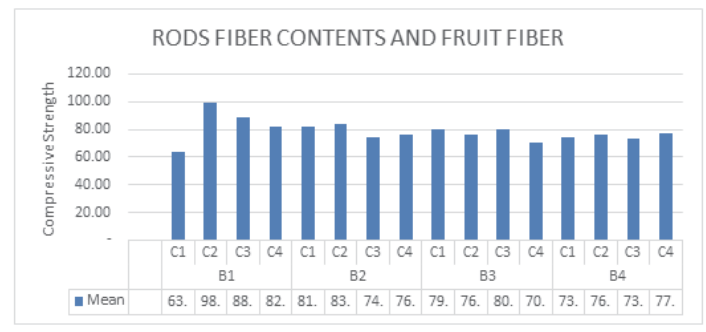

Figure 3. The compressive strength with additional materials of rods fiber contents and Palmyra fruit fiber

Based on Figure 3, The smallest percentage specimen compressive strength of rods fiber and fruit fiber are at level B1 and $\mathrm{C} 1(0 \%)$ with an average of $63,70 \mathrm{Kg} / \mathrm{cm}^{2}$ while the highest percentage of rods fiber and fruit fiber are at level B1 $(0 \%)$ and $\mathrm{C} 2(3 \%)$ with an average of $98.82 \mathrm{Kg} / \mathrm{cm}^{2}$. The increase in the percentage addition of rods fiber running high at the level of $3 \%$, decreased in adding $6 \%$ and $9 \%$ in compressive strength solid concrete brick, from the analysis of the increase in compressive strength averaged $24,88 \%$ on solid concrete brick used additional materials of rods fiber contents and Palmyra fruit fiber. Compressive strength to be decreased with percentage (10,15 and 20\%), Mokhtari et al., (2015), Natural fibers can withstand cracking that occurs in solid concrete bricks it is supported by Prima et al., (2014) Figure 4 proves that the fibers of the palmyra fruit does not break at the time of the test object is destroyed, The larger the addition of palm fiber, the greater the compressive strength of concrete block, brick compressive strength value with the addition of palm fiber $0 \%, 2 \%, 4 \%$ and $6 \%$ amounted to $25,47 \mathrm{~kg} / \mathrm{cm} 2 ; 28,55 \mathrm{~kg} / \mathrm{cm} 2 ; 30,33 \mathrm{~kg} / \mathrm{cm} 2 ;$ and $33,36 \mathrm{~kg} / \mathrm{cm}^{2}$ meet the eligibility criteria of solid concrete brick IV (Hermanto D., et al., 2014).

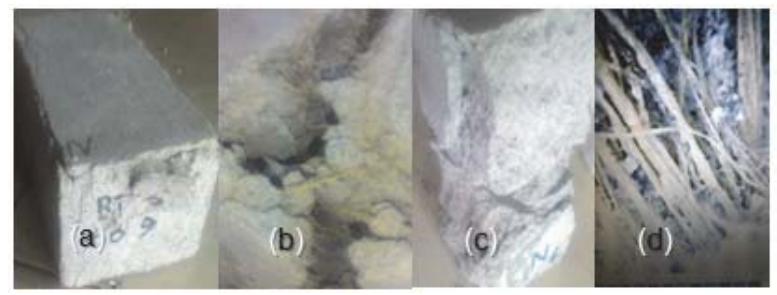

Figure 4: (a) The test object is still intact after a compressive strength test, (b) Fiber palmyra does not break when the test object is destroyed, (c) The test object without using fibers being crushed when testing the compressive strength, (d) Fibre still intact after 6 months of the test object is destroyed.

\section{Conclusion}

The test results on the compressive strength of solid concrete brick with additional material Palmyra rods fiber contents has decreased quality, due to the diameter of rod fiber which the average diameter of $1,03 \mathrm{~mm}$ had an average compressive strength of $76,97 \mathrm{Kg} / \mathrm{cm}^{2}$, broad surface causes the more of water absorption.

The results of compressive strength testing showed that the solid concrete brick with additional materials palmyra fruit fibers with an average diameter of $0,40 \mathrm{~mm}$ had an average compressive strength $79,83 \mathrm{Kg} / \mathrm{cm}^{2}$, the highest level in the use of fruit fiber $3 \%$.

The results of compressive strength testing of concrete brick solid combination with additional materials of the rod fiber content and Palmyra fruit fiber can improve the quality of the test results with the highest value on the combination of additional materials $0 \%$ rod fiber content, and $3 \%$ fruit fiber, with a compressive strength of average by $98,82 \mathrm{Kg} / \mathrm{cm}^{2}$, 
caused a smaller fiber diameter and wrapped perfectly by cement, evident after the specimen was broken but the fruit fiber is still intact.

The use of the rods fiber content and Palmyra fruit as an additive in solid concrete brick can anticipate the cracks and may increase the compressive strength of $24.88 \%$ when compared with solid concrete brick without using additional material of Palmyra fiber. Rods fiber contents and fruit fiber of Palmyra palm is a kind of natural fibers that are not traded, utilize fiber from Palmyra palm, as the building material is an effort to lower production costs and environmental impacts as well as one of the alternatives in anticipation of raw material consumption of nonrenewable.

\section{References}

Abanat J.D.J., et al., 2012, Effect of fiber volume fraction of Gebang palm (Corypha Utan Lamarck) on Mechanical Properties, The Epoxy Matrix Composites, Journal of Engineering Machinery Vol.3, No. 2 Year 2012 : 352-361 ISSN 0216-468X

Abani. S1, Hafsi. F1, Kriker. A ${ }^{1}$, Bali. A2 , Valorisation of Date Palm Fibres in Sahara Constructions, International Conference on Technologies and Materials for Renewable Energy, Environment and Sustainability, TMREES15, Energy Procedia 74 ( 2015 ) $289-293$

Bachtiar D., Sapuan S.M., Khalina A., Zainudin E.S., and Dahlan K.Z.M., (2011), The Flexural, Impact and Thermal Properties of Untreated Short Sugar Palm Fiber Reinforced High Impact Polystyrene (Hips) Composites, department Of Mechanical And Manufacturing Engineering, University of Putra Malaysia, 43400 Serdang, Selangor, Malaysia Received: 16 August 2010, Accepted: 12 September 2011

Boimau K., Dominggus G. H. Adoe, Wenseslaus B, Yusak M. B., (2012), Effect of Fiber Volume Fraction of Hybrid Composites Tensile Strength with amplifier Palmyra palm fibers and Glass Fiber, National Seminar on Science and Engineering 2012 (SAINSTEK 2012)Kupang, 13 November 2012

Bolden J.J., (2013) Innovative uses of Recycled and Waste Materials in Construction Application IV North Carolina A. \& T State University Published by ProQuest LLC (2013). Copyright in the Dissertation held by the Author, Microform Edition ( ) ProQuest LLC. All rights reserved. This work is protected against unauthorized copying under Title 17, United States Code

Hartono, (2011), Study of the use of cement brick with Aggregate of wood shawn waste as Wall Construction Building Materials , Journal of Civil Engineering Forum Vol.16 No.2 December 2011 87-95

Imuagwu Ben Ugochukwua, Iwuagwu Ben Chioma M ${ }^{b}$, Local Building Materials: Affordable Strategy For Housing The Urban Poor In Nigeria, International Conference On Sustainable Design, Engineering And Construction, Procedia Engineering 118 (2015) 42 49

Kurniaty D.R., Rizal M., (2011) Utilization of Waste Management Results as an Alternative Building Materials Construction, Journal Smartek, Vol. 9 No. 1. February 2011: 47 - 60

Lestari I, Bagyo Yanuwiadi, Soemarno, (2013) Local Vegetation Suitability Analysis for Green Open Space Trails Road in Kupang City Center, J-PAL, Vol. 4, No. 1, 2013

Lempang M., M. Asdar dan Alfrida Limbong (2012) Anatomical characteristics, physical and mechanical properties, and utilities of Palmyra palm rods, Anatomical Features, Physical and Mechanical Properties, and Uses of Lontar Stem

Machaka M., Basha H., Chakra H.A., Elkordi A., (2014), Alkali Treatment of Fan Palm Natural Fibers For Use In Fiber Reinforced Concrete, European Scientific Journal April 2014 Edition Vol.10, No.12 ISSN: 1857 - 7881 (Print) E - ISSN 1857- 7431

Mokhtari A. (A) Kriker A. (A) Guemmoula Y.(A) Boukrioua A.(A) Khenfer M.M. (B), Formulation And Characterization of Date Palm Fibers Mortar by Addition of Crushed Dune Sand, International Conference on Technologies and Materials For Renewable Energy, Environment and Sustainability, Tmrees15, Energy Procedia 74 ( 2015 ) 344 - 350

Mizwar, A., Agustini, E., Samudra, G. and Auliannoor, M. 2012. Utilization Mud Marble, Waste Styrofoam and Coal Fly Ash to Manufacture the Concrete brick Perforated. Journals of INTEKNA ISSN 1412-5609, vol. 12(1), 10-16.

Nugroho, M. D., Annur M.D.R., (2014) Cow Manure Utilization for Construction Materials in Efforts Solving Social Problems and Enhancing Community Economic Level, State Polytechnic of Bandung, Journal socio-technology, Volume 13, Number 2, August 2014, accessed January 28, 2015

Suwarto, Isnadi,Triatmo Sugih Hardono, 2011), Study of Utilization of Fiber Reeds For Making Lightweight hollow Bricks, Department of Civil Engineering, State Polytechnic of Semarang, Journal, Civil Engineering Forum Vol.16 No.2 December 2011 68-76

Susandra D., Kasim A. and Sulastri E., (2014) Study Utilization of sawdust as raw material Paving Block Making, Journal of the Faculty of Forestry, University of Muhammadiyah of West Sumatra, Street. Pasir Kandang No. 4, Kototangah, Phone. (0751) 481777, 481645, 482274 Padang (25172) 